\title{
TEPUNG TALAS BOGOR TERMODIFIKASI HASIL OKSIDASI MENGGUNAKAN HIDROGEN PEROKSIDA DENGAN DAN TANPA IRADIASI SINAR UV
}

\section{MODIFIED BOGOR TARO FLOUR USING HYDROGEN PEROXIDE WITH AND WITHOUT UV LIGHT IRRADIATION}

\author{
Riyanti Ekafitri ${ }^{1,2}$, Yudi Pranoto1, Ainia Herminiati², Taufik Rahman² \\ ${ }^{1}$ Fakultas Teknologi Pertanian, Universitas Gajah Mada, \\ ${ }^{2}$ Pusat Pengembangan Teknologi Tepat Guna Lembaga Ilmu Pengetahuan Indonesia, \\ Jl.K.S.Tubun No. 5 Subang, Jawa Barat \\ Alamat Email: riyantiekafitri@yahoo.com
}

Diterima : 23-07-2018 Direvisi : 30-07-2018 Disetujui : 08-08-2018

\begin{abstract}
ABSTRAK
Peningkatan mutu tepung talas dapat dilakukan dengan modifikasi secara kimia melalui proses oksidasi menggunakan hidrogen peroksida yang dikatalis dengan iradiasi UV. Tujuan penelitian ini adalah mengamati karakteristik tepung talas yang dioksidasi dengan hidrogen peroksida dan diberi perlakuan dengan dan tanpa iradiasi sinar UV selama waktu tertentu. Rancangan percoban yang digunakan adalah rancangan acak lengkap dengan 2 faktor: (1) perlakuan tanpa dan dengan iradiasi UV dan (2) waktu reaksi selama 5, 15, dan 30 menit. Analisa yang dilakukan diantaranya: proksimat, kandungan karboksil, nilai L, a, b, profil gelatinisasi, swelling power dan baking expansion. Hasil menunjukkan bahwa komposisi kimia tepung talas bogor terbesar adalah komponen pati $(84,03 \%)$. Perlakuan oksidasi tepung talas dengan hidrogen peroksida tanpa atau disertai dengan iradiasi UV mengubah sifat fisiko kimia dan baking expansion tepung talas: meningkatkan kandungan karboksil, menurunkan kecerahan warna (nilai L, a, b), meningkatkan swelling power dan baking expansion, meningkatkan peak viscosity, final viscosity, dan breakdown viscosity, menurunkan setback viscosity, peak time dan peak temperature, dibandingkan dengan tepung talas alami. Perlakuan oksidasi hidrogen peroksida dengan iradiasi UV memiliki karakteristik kandungan karboksil yang lebih tinggi, nilai L, a, b yang lebih rendah, dan peak viscosity, final viscosity, serta breakdown viscosity yang lebih tinggi dibandingkan dengan perlakuan oksidasi hidrogen peroksida secara tunggal. Waktu oksidasi/oksidasi-iradiasi (5-30 menit) tidak berpengaruh signifikan pada sebagian besar parameter uji. Baking expansion tepung talas tertinggi dihasilkan pada perlakuan oksidasi dengan iradiasi UV selama 15 menit sebesar $32,46 \%$.
\end{abstract}

Kata kunci : tepung talas, oksidasi, iradiasi UV

\section{ABSTRACT}

To improve the quality of taro flour can be done by oxidation process using hydrogen peroxide catalyzed by UV irradiation. The objective of this study was to observe the characteristics of taro flour which was oxidized with hydrogen peroxide and treated with and without UV irradiation for a certain time. The experimental design used was a complete randomized design with 2 factors: (1) treatment without and with UV irradiation and (2) reaction time for 5, 15, and 30 minutes. Analyzes conducted include: proximate, carboxyl content, $L, a, b$, gelatinization profile, swelling power and baking expansion. The results showed that the largest chemical composition of taro flour was the starch component (84.03\%). Oxidation of taro flour with hydrogen peroxide without or with UV irradiation changes the physicochemical properties and baking expansion of taro flour: increases carboxyl content, decreases color brightness $(L, a, b)$, increases swelling power and baking expansion, increases peak viscosity, final viscosity, and breakdown viscosity, decreases setback viscosity, peak time and peak temperature compared with native taro flour. The hydrogen peroxide oxidation treatment with UV irradiation has higher carboxyl contents, lower $L, a, b$, and peak viscosity, final 
viscosity, and higher viscosity breakdown than taro flour which was oxidized by hidrogen peroxide without UV irradiation. Oxidation/oxidation-irradiation time (5 to 30 minutes) give no significant effect on almost all parameters. The highest baking expansion of taro flour was produced in the oxidation treatment with UV irradiation for 15 minutes as much as $32.46 \%$.

\section{Keywords: taro flour oxidation, UV irradiation}

\section{PENDAHULUAN}

$\mathrm{T}$

epung dan pati merupakan salah satu produk antara yang dibutuhkan dalam berbagai aplikasi pangan. Di industri pangan, tepung dan pati digunakan sebagai bahan baku dalam pembuatan roti, sereal sarapan, pasta, saus, sup, confectionary, coating, dan produk daging (Vanier et al., 2017). Modifikasi tepung dan pati telah banyak dilakukan dengan tujuan untuk memperbaiki sifat tepung dan pati alami sehingga sesuai dengan aplikasi pangan yang diinginkan. Menurut Zhou et al. (2016) tepung dan pati alami memiliki sifat stabilitas terhadap panas yang buruk, ketahanan terhadap pemanasan yang rendah, dan mudah mengalami retrogradasi sehingga perlu dilakukan modifikasi untuk mengatasi kelemahan-kelemahan tersebut salah satunya dengan modifikasi kimia yaitu proses oksidasi.

Selama proses oksidasi, gugus hidroksil pada molekul pati akan teroksidasi menjadi gugus karbonil dan kemudian menjadi gugus karboksil. Jumlah gugus karbonil dan karboksil yang terbentuk mengindikasikan tingkat oksidasi yang terjadi (Vanier et al., 2017). Selain itu, proses oksidasi juga mengakibatkan perubahan pada profil gelatinisasi (Dias et al., 2011), dan peningkatan baking expansion (Sausania 2014; Thetool et al., 2012a,2012b). Tepung atau pati teroksidasi memiliki viskositas rendah, stabilitas panas yang tinggi, retrodagrasi rendah, daya ikat, sifat pembentukan film, dan kejernihan yang lebih baik dibandingkan pati alami, sehingga dapat memperluas penggunaannya pada berbagai produk olahan pangan seperti untuk produk cake (Budiyati dan Dessy, 2014), pembuatan sup kental (Zhou et al., 2016), biodegradable film (Fonseca et al., 2015), dan sebagai binder untuk produk confectionary (Singh et al., 2007). Hal ini menunjukkan bahwa perubahan sifat fungsional pada tepung teroksidasi memperluas penggunaan tepung pada berbagai aplikasi pangan.

Salah satu metode oksidasi pati adalah dengan menggunakan oksidator seperti hidrogen peroksida. Dias et al. (2011) menyatakan bahwa hidrogen peroksida merupakan oksidator yang banyak digunakan secara komersial dan tidak menyebabkan hasil samping yang berbahaya. Peningkatan tingkat oksidasi pati, dapat dilakukan dengan menggunakan sinar UV sebagai katalisator. Oksidasi dengan katalisator UV dipengaruhi oleh intensitas (Sausania, 2014), waktu penyinaran (Sausania, 2014; Tethool et al., 2012a), jenis sinar UV (Vatanasuchart et al., 2005), dan konsentrasi slurry. Menurut Thetool et al., (2012a) iradiasi UV pada pati sagu teroksidasi pada konsentrasi slurry 1:6, selama 15 menit meningkatkan gugus karbonil, karboksil, swelling power, kelarutan, viskositas puncak, viskositas pasta panas, viskositas pasta dingin, kandungan amilosa akibat depolimerasi rantai pati, dan baking expansion pati sagu sebesar $65,6 \%$ dibandingkan dengan pati alami.

Indonesia memiliki banyak tanaman umbi umbian yang berpotensi diolah menjadi tepung atau pati. Salah satu jenis umbi tradisional Indonesia adalah talas. Menurut Arici et al. (2016) tepung talas memiliki total pati 58,5-63\%, pati resisten 33,5-51,4\%, serat pangan $12,8-14,0 \%$, dan komponen fenolik 1,2-4,17 g GA/L, serta kandungan mineral yang cukup lengkap. Sementara menurut Ekafitri (2017), tepung talas memiliki kadar air 9,30\%, kadar abu 0,76 \%, kadar lemak 0,31\%, kadar protein 3,36\%, kadar serat kasar 2,00, kadar pati 84,03, dan kadar amilosa 13,26.

Pati dalam tepung talas memiliki kelemahan diantaranya kecenderungan retogradasi tinggi, kestabilan dan ketahanan pasta yang rendah serta mengandung oksalat yang 
menyebabkan iritasi pada jaringan bila dikonsumsi. Hal ini mengakibatkan keterbatasan tepung talas dalam aplikasinya pada proses pengolahan.

Proses modifikasi kimia yang dilakukan terhadap tepung talas untuk meningkatkan mutu tepung talas dilakukan oleh Budiyati dan Dessy (2014) yaitu dengan penggunaan hidrogen peroksida sebanyak $2 \%$ tanpa iradiasi sinar UV. Belum ditemukan adanya penelitian yang melihat pengaruh proses oksidasi hidrogen peroksida yang dikatalis dengan sinar UV. Oleh karena itu penelitian ini bertujuan untuk mengamati karakteristik tepung talas yang dioksidasi dengan hidrogen peroksida dan diberi perlakuan dengan dan tanpa iradiasi sinar UV selama waktu tertentu.

\section{BAHAN DAN METODE}

\section{Bahan dan Alat}

Bahan utama yang digunakan dalam penelitian ini adalah umbi talas bogor (Colocasia esculanta L Schoot) dengan usia panen 8 bulan yang diperoleh dari pasar Bogor, garam, hidrogen peroksida $30 \%$, dan bahan kimia untuk analisa. Alat yang digunakan dalam peneltian ini adalah slicer, cabinet dryer, vibrator screen, alat katalisator UV, oven pemanggang, dan peralatan analisa seperti: Colorimeter (NH310, China), Rapid Visco Analyzer (RVA-Tec Master Perten, Sweden).

\section{Metodologi}

Kegiatan penelitian dibagi menjadi beberapa tahapan yaitu: pembuatan tepung talas, oksidasi dan iradiasi tepung talas, dan pengamatan karakteristik tepung talas yang dihasilkan.

\section{Persiapan tepung talas (Aprianita et al., 2014 dengan modifikasi)}

Tepung talas dibuat dari umbi talas bogor (Colocasia esculanta L .Schoot). Umbi talas bogor dikupas kemudian di potong dan dicuci untuk menghilangakn getah. Selanjutnya dilakukan pengecilan ukuran terhadap umbi talas menggunakan alat slicer. Kemudian irisan umbi talas direndam dalam larutan $\mathrm{NaCl} 10 \%$ untuk menurunkan kadar oksalat yang dapat menyebabkan rasa gatal dan iritasi jaringan apabilla dikonsumsi. Setelah itu dilakukan pencucian sebanyak 5 kali, perendaman kembali, penirisan, dan diikuti dengan pengeringan menggunakan cabinet dryer hingga diperoleh irisan talas kering. Irisan talas kering kemudian ditepungkan dan diayak sehingga dihasilkan tepung talas.

\section{Oksidasi/oksidasi-iradiasi tepung talas (Tethool et al., 2012a, 2012b)}

Tepung talas yang diperoleh dioksidasi menggunakan alat katalisator UV. Tepung talas dan air hasil reverse osmosis dengan perbandingan 1:5 dicampurkan dengan oksidator hidrogen peroksida sebanyak $2 \%$ dari berat kering tepung talas dalam tangki katalisator UV. Kemudian dilakukan pengadukan untuk mencegah terjadinyleboha pengendapan yang diikuti dengan pengaliran s/urry tepung yang terbentuk dalam tabung iradiasi UV selama waktu perlakuan 5; 15; 30 menit. Untuk perlakuan tanpa iradiasi, terhadap s/urry tepung hanya tambahkan hidrogen peroksida disertai pengadukan tanpa pengaliran dalam tabung iradiasi UV. Setelah proses oksidasi dan iradiasi berhenti, slurry tepung disentrifuse dengan kecepatan $1200 \mathrm{~g}$ selama 5 menit dan dicuci sebanyak 3 kali. Selanjutnya cake tepung yang diperoleh dikeringkan hingga diperoleh tepung talas hasil modifikasi dengan kadar air 10$13 \%$. 


\section{Analisa}

Analisa kimia yang dilakukan meliputi kadar air, lemak, protein, abu dan serat kasar (AOAC, 1995), kadar karbohidrat (difference method), uji kandungan karboksil (Demiate et al., 2000 dengan modifikasi), analisa warna (Rapid Visco Analyser Tec Master) (Khausal et al., 2012), analisa baking property (Setya, 2015), swelling power (Tester and Morison, 1990), Profil gelatinasi (Khausal et al., 2012 dengan modifikasi).

Penelitian ini menggunakan Rancangan Acak Lengkap (RAL) untuk mengetahui karakteristik tepung talas oksidasi hidrogen peroksida yang dihasilkan dari perlakukan dengan dan tanpa iradiasi UV dan waktu oksidasi/ oksidasi-iradiasi. Data yang diperoleh selanjutnya dianalisa menggunakan ANOVA dengan uji lanjut Duncan.

\section{HASIL DAN PEMBAHASAN}

\section{Karakteristik tepung talas bogor termodifikasi Kandungan karboksil}

Selama proses oksidasi gugus hidroksil pada molekul pati akan pertama kali teroksidasi menjadi gugus karbonil dan kemudian gugus karboksil. Jumlah gugus karboksil yang terbentuk merupakan salah satu indikasi tingkat oksidasi yang terjadi (Vanier et al., 2017). Kandungan gugus hidroksil tepung talas alami dan yang diberi perlakukan dengan dan tanpa iradiasi sinar UV selama 5-30 menit ditunjukkan pada Tabel 1.

Tabel 1 menunjukkan bahwa kandungan karboksil tepung talas tiap perlakuan berbeda signifikan $(p \leq 0,05)$. Kandungan karboksil tepung talas hasil oksidasi hidrogen peroksida dan oksidasi hidrogen peroksida-iradiasi sinar UV berkisar antara 0,0517-0,0812\%. Nilai ini lebih rendah dibandingkan kadar karboksil pati sagu yaitu 0,23-0,44\% dengan perlakuan oksidasiiradiasi selama 10-20 menit (Tethool et al., 2012b) tetapi lebih tinggi dibandingkan dengan kandungan karboksil pada pati jagung yaitu 0,019-0,049\% dengan perlakuan oksidasi menggunakan natrium hipoklorit (Shandu et al., 2008). Kandungan karboksil tepung talas ini cukup rendah. Menurut El-Sheikh et al. (2010) selama reaksi, sejumlah pati teroksidasi terrdegradasi menjadi lebih larut air, sehingga terbuang saat proses pencucian bersama dengan kandungan gugus karbonil dan karboksil.

Tabel 1. Karakteristik tepung talas bogor termodifikasi hasil perlakukan oksidasi dan oksidasi-iradiasi UV selama 5-30 menit dibandingkan dengan tepung talas alami

\begin{tabular}{|c|c|c|c|c|c|c|c|c|}
\hline \multicolumn{2}{|c|}{ Perlakuan } & \multirow[b]{2}{*}{$\begin{array}{c}\text { Kandungan } \\
\text { karboksil } \\
(\%)^{*}\end{array}$} & \multicolumn{3}{|c|}{ Warna } & \multirow[b]{2}{*}{$\begin{array}{c}\text { Swelling } \\
\text { power } \\
(\mathrm{g} / \mathrm{g})^{*}\end{array}$} & \multirow[b]{2}{*}{$\begin{array}{l}\text { Volume } \\
\text { spesifik } \\
(\mathrm{ml} / \mathrm{g})^{*}\end{array}$} & \multirow[b]{2}{*}{$\begin{array}{c}\text { Baking } \\
\text { expansion } \\
(\%)\end{array}$} \\
\hline $\begin{array}{l}\text { Tanpa } \\
\text { dan } \\
\text { dengan } \\
\text { iradiasi } \\
\text { UV }\end{array}$ & $\begin{array}{l}\text { Waktu } \\
\text { oksidasi/ } \\
\text { oksidasi- } \\
\text { iradiasi } \\
\text { (menit) }\end{array}$ & & $\mathrm{L}$ & a & b & & & \\
\hline Alami & - & $0,0002^{a}$ & $82,75^{a}$ & $2,20^{a}$ & $6,38^{a}$ & $9,31^{a}$ & $2,91^{a}$ & - \\
\hline \multirow{3}{*}{$\begin{array}{l}\text { Tanpa } \\
\text { iradiasi } \\
\text { UV }\end{array}$} & 5 & $0,0517^{a}$ & $82,23^{a b}$ & $2,20^{a b}$ & $5,24^{b c}$ & $10,68^{\mathrm{ab}}$ & $3,40^{a b}$ & 16,72 \\
\hline & 15 & $0,0595^{b}$ & $81,81^{b c}$ & $1,76^{b}$ & $5,47^{b}$ & $10,59^{\mathrm{ab}}$ & $3,55^{b}$ & 21,81 \\
\hline & 30 & $0,0649^{b c}$ & $81,42^{\text {cd }}$ & $1,95^{c}$ & $5,01^{c}$ & $10,15^{\mathrm{ab}}$ & $3,52^{b}$ & 20,80 \\
\hline \multirow{3}{*}{$\begin{array}{l}\text { Dengan } \\
\text { iradiasi } \\
\text { UV }\end{array}$} & 5 & $0,0727^{\mathrm{cd}}$ & $81,09^{\text {cd }}$ & $1,63^{b c}$ & $5,30^{\mathrm{bc}}$ & $11,51^{b}$ & $3,41^{a b}$ & 17,27 \\
\hline & 15 & $0,0812^{d}$ & $81,04^{\text {cd }}$ & $1,76^{b}$ & $5,09^{c}$ & $10,73^{\mathrm{ab}}$ & $3,86^{b}$ & 32,46 \\
\hline & 30 & $0,0698^{\text {de }}$ & $80,95^{d}$ & $1,59^{c}$ & $5,13 b^{c}$ & $11,04^{b}$ & $3,52^{b}$ & 23,77 \\
\hline
\end{tabular}

* superscript yang sama pada kolom yang sama menunjukkan sampel tidak berbeda nyata pada taraf signifikansi 5\%berdasarkan analisa sidik ragam ANOVA dan uji lanjut Duncan. 
Tepung talas yang diberi perlakukan iradiasi siar UV memiliki kandungan karboksil yang lebih tinggi dibandingkan dengan tepung talas yang hanya diberi perlakuan oksidasi hidrogen peroksida tanpa iradiasi sinar UV selama 5-30 menit dan semakin lama waktu oksidasi/oksidasi-iradiasi, kandungan karboksil tepung talas semakin meningkat. Tethool et al. (2012a, 2012b) mengkombinasikan penggunaan hidrogen peroksida dengan sinar UV sebagai foto inisiator menghasilkan gugus karbonil dan karboksil yang lebih tinggi dibandingkan penggunaan hidrogen peroksida secara tunggal pada pati sagu. Hidrogen peroksida oleh adanya iradiasi UV menghasilkan radikal bebas dan keberadaan gugus hidroksil pada pati berperan sebagai donor hidrogen. Radikal bebas yang dihasilkan akan beraksi dengan gugus hidroksil pada molekul pati membentuk pati makroradikal yang selanjutnya memicu pembentukan gugus karbonil dan karboksil (El-Sheikh et al., 2010). Waktu oksidasi juga merupakan salah satu faktor yang mempengaruhi oksidasi pada pati. Semakin lama waktu iradasi, proses oksidasi semakin intensif (Dewi, 2011). Kandungan karboksil tertinggi pada perlakuan oksidasi hidrogen peroksida dan iradiasi sinar UV selama 15 menit $(0,0812 \%)$ kemudian menurun pada perlakuan oksidasi-iradiasi selama 30 menit $(0,0698 \%)$. Peningkatan karboksil ini dapat disebabkan oleh oksidasi lanjut gugus karbonil menjadi gugus karboksil dan setelah 15 menit terjadi reaksi dekarboksilasi yang menyebabkan penurunan gugus kaboksil (El-Sheikh et al., 2010).

\section{Warna}

Tabel 1 menunjukkan pengaruh perlakukan oksidasi dan oksidasi-iradiasi tepung talas selama 5-30 menit terhadap parameter warna tepung talas. Nilai L menunjukkan tingkat kecerahan sampel. Semakin cerah sampel yang diukur, maka nilai L akan mendekati 100 . Sebaliknya semakin gelap sampel, nilai $L$ akan mendekati 0 . Nilai a merupakan parameter pengukuran warna kromatik campuran merah-hijau. Bila a bernilai positif, sampel cenderung berwarna merah. Sebaliknya, bila a bernilai negatif maka sampel cenderung berwarna hijau. Nilai b merupakan parameter pengukuran warna kromatik campuran kuning-biru. Bila $b$ bernilai positif, sampel cenderung berwarna kuning dan bila $b$ bernilai negatif maka sampel cenderung berwarna biru.

Tepung talas alami secara subjektif memiliki warna putih agak kemerahan dan berdasarkan pengamatan kuantitatif dengan colorimeter tepung talas memiliki nilai $L$ sebesar 82,97 , a sebesar 2,13 dan b sebesar 6,08. Nilai $L$ sebesar 82,97 pada tepung talas menunjukkan tepung talas memiliki warna yang putih yang cukup cerah. Nilai a sebesar 2,13 tepung talas menunjukkan tepung talas memiliki kecenderungan berwarna merah yang dapat disebabkan oleh warna merah muda pada bagian kulit talas yang terikut saat penepungan dan nilai $b$ sebesar 6,08 menunjukkan tepung talas juga memiliki kecenderungan berwarna kuning. Hal ini sesuai dengan yang diungkap oleh Aboubakar et al. (2008) bahwa tepung talas memiliki warna putih (nilai $L$ yang tinggi), sedikit merah (nilai a rendah) dan sedikit kuning (nilai $b$ rendah). Nilai kuning pada tepung talas dapat disebabkan oleh sejumlah karbohidrat dan protein yang berperan dalam pengembangan pencoklatan enzimatik (Jamin dan Flores, 1998).

Pada Tabel 1 terlihat bahwa perlakuan oksidasi dan oksidasi-iradiasi UV pada tepung talas menyebabkan penurunan nilai $L$, $a$, dan $b$ yang berbeda signifikan dibandingkan dengan tepung talas alami $(p \leq 0,05)$. Perlakuan dengan iradiasi UV memiliki nilai $L, a, b$ yang lebih rendah $(80,95-81,09 ; 1,59-1,76 ; 5,09-5,30)$ dibandingkan dengan tepung talas yang hanya dikenai perlakuan oksidasi hidrogen peroksida $(81,42-82,23 ; 1,76-2,20 ; 5,01-5,47)$. Semakin lama waktu oksidasi/oksidasi-iradiasi terlihat kecenderungan nilai $L$, $a$, dan b yang semakin menurun. Menurut Jenie et al. (1997) oksidasi merupakan salah satu faktor yang menyebabkan penurunan mutu warna. Hidrogen peroksida oleh adanya iradiasi UV menghasilkan radikal bebas yang dapat mengoksidasi komponen dalam tepung talas seperti 
fenolik, protein, lemak yang menyebabkan penurunan kecerahan warna tepung. Hal ini serupa dengan yang terjadi pada oksidasi dan iradiasi pati sagu selama 10 menit menunjukkan terjadinya penurunan kecerahan pati. Hal ini diduga karena adanya enzim polifenolase pada pati sagu yang memicu terjadinya pencoklatan enzimatik (Thethool et al., 2012b). Aktivitas enzim polifenolasi meningkat dengan adanya sinar UV mengakibatkan pencoklatan enzimatik yang lebih tinggi. Hasil penelitian ini berbeda dengan pati pisang yang dioksidasi menggunakan natrium hipoklorit yang menghasilkan peningkatan kecerahan (L) (Rivera et al., 2005).

Adanya reaksi oleh hidrogen peroksidas dan iradiasi UV sebagai photosensitizer menyebabkan terjadinya oksidasi yang lebih efektif sehingga menurunkan nilai a dan $b$. Menurut Rivera et al. (2005), pada reaksi oksidasi, sebagian pigmen dan protein teroksidasi terlebih dahulu sebelum unit glukosa sehingga senyawa-senyawa tersebut sebagian akan hilang, mengakibatkan pengurangan intensitas warna kuning pada tepung (nilai b). Hal yang sama diduga terjadi pada pengurangan intensitas warna merah (nilai a) pada tepung.

\section{Swelling power}

Swelling power adalah kemampuan pati untuk menghidrasi pada kondisi tertentu (Vanier et al., 2017) yang ditentukan dengan pengukuran berat granula pati yang membengkak dan air yang terserap dan tertahan dalam granula pati (Falade dan Chidinma, 2015). Swelling power tepung talas alami dan tepung talas perlakukan oksidasi dan oksidasiiradiasi tepung talas selama 5-30 menit disajikan pada Tabel 1. Swelling power tepung talas alami sebesar 9,31 $\mathrm{g} / \mathrm{g}$ lebih tinggi dibandingkan dengan dengan swelling power yang dilaporkan oleh Falade dan Chidinma (2015) dan Budiyati dan Dessy (2014) yaitu 3,18-4,81 dan $4,03 \mathrm{~g} / \mathrm{g}$. Tepung talas hasil oksidasi/oksidasi iradiasi memiliki swelling power yang lebih tinggi dan berbeda signifikan dibandingkan dengan swelling power tepung talasi $(p \leq 0,05)$. Perlakuan tanpa dan dengan iradiasi UV serta lama waktu oksidasi/ oksidasi-iradiasi tidak menunjukkan perbedaan nilai swelling power yang signifikan berbeda $(p \geq 0,05)$. Namun, penggunaan iradiasi UV memiliki kecenderungan swelling power yang lebih tinggi $(10,73-$ $11,51 \mathrm{~g} / \mathrm{g}$ ) dibadingkan perlakuan tanpa iradiasi UV $(10,15-10,68 \mathrm{~g} / \mathrm{g})$. Peningkatan swelling power pada tepung talas teroksidasi ini disebabkan oleh depolimerisasi rantai amilosa yang mengurangi derajat kristalinitas dan menyebabkan molekul air masuk dalam rantai amilopektin sehingga meningkatkan swelling power tepung (Budiyati dan Dessy, 2014).

\section{Baking property}

Tabel 1 menunjukkan volume spesifik dan sifat baking expansion tepung talas alami dan tepung talas dengan perlakukan oksidasi dan oksidasi-iradiasi tepung talas selama 5-30 menit. Tepung talas alami memiliki volume spesifik sebesar $2,91 \mathrm{ml} / \mathrm{g}$ yang meningkat signifikan pada perlakuan oksidasi hidrogen peroksida tanpa dan dengan iradiasi UV ( $p$ $<0,05$ ) menjadi 3,40-3,86 $\mathrm{ml} / \mathrm{g}$. Perlakuan dengan dan tanpa iradiasi UV tidak menunjukkan perbedaan volume spesifik yang signifikan berbeda $(p \geq 0,05)$. Tepung talas hasil perlakuan oksidasi hidrogen peroksida yang disertai dengan iradiasi UV selama 15 menit menunjukkan volume spesifik tertinggi sebesar $3,86 \mathrm{ml} / \mathrm{g}$ atau derajat pengembangan (baking expansion) meningkat $32,46 \%$ dibandingkan tepung talas alami $(2,91 \mathrm{ml} / \mathrm{g})$. Sedangkan volume spesifik terendah dihasilkan dari dari perlakuan oksidasi hidrogen peroksida tanpa perlakuan UV selama 5 menit yaitu $3,40 \mathrm{ml} / \mathrm{g}$ atau baking expansion meningkat hanya $16,72 \%$ dibandingkan tepung alami

Oksidasi dengan hidrogen peroksida disertai irradiasi UV menghasilkan volume spesifik yang lebih besar selama 15 menit waktu reaksi dibandingkan tanpa irradiasi UV dan perlakuan lainnya disebabkan karena iradiasi UV menyebabkan proses oksidasi berlangsung lebih efektif dan menghasilkan gugus karbonil dan karboksil yang lebih banyak sehingga 
kemampuan pati mengikat air dan mengembang pada saat pemanggangan menjadi lebih besar (Vatanasuchart et al., 2005; Sangseethong, 2010). Peningkatan kapasitas hidrasi pati berkontribusi pada peningkatan daya ikat air dalam molekul pati, sehingga mempengaruhi penguapan air dan tekanan internal selama proses pemanggangan (Thetool et al., 2012b). Namun Anindya dan Haryadi (2014) menyatakan bahwa baking expansion yang tinggi tidak ditunjukkan dengan tingginya pembentukan gugus karbonil dan karboksil. Hal ini disebabkan kesetimbangan antara jumlah gugus karbonil dan karboksil yang dibutuhkan untuk mendapatkan tingkat pengembangan maksimal (Dias et al., 2011).

\section{Profil gelatinisasi tepung talas bogor}

Granula pati dapat dibuat membengkak luar biasa tetapi bersifat tidak dapat kembali lagi pada kondisi semula. Perubahan tersebut disebut gelatinisasi. Alay dan Maria (2015) menyatakan gelatinisasi terjadi saat pati dipanaskan pada kondisi air berlebih, yaitu saat air terdifusi kedalam granula pati kemudian mengembang disebabkan oleh hidrasi fase amorphous menyebabkan hilangnya kristalinitas. Syamsir et al. (2012) menyatakan bahwa fenomena yang mengikuti gelatinisasi disebut dengan pasting. Gambar 1 menunjukkan pengaruh perlakukan oksidasi dan oksidasi-iradiasi tepung talas selama 5-30 menit terhadap profil gelatinisasi tepung talas dibandingkan dengan profil gelatinisasi tepung talas alami.

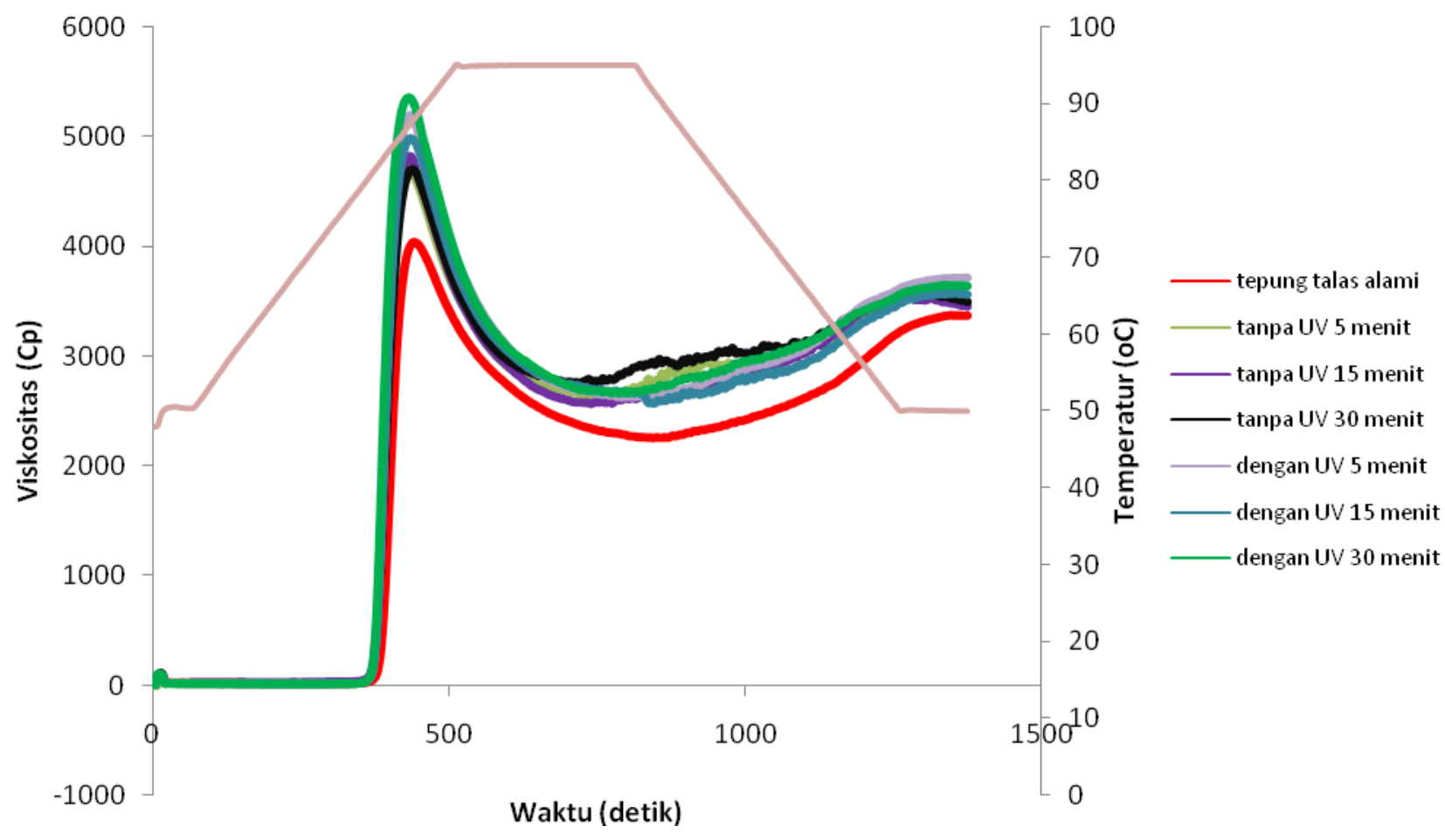

Gambar 1. Profil gelatinisasi tepung talas bogor alami dan hasil modifikasi oksidasi hidrogen peroksida dengan dan tanpa perlakuan UV

Peak viscosity (viskositas maksimum) titik maksimum viskositas pasta yang dihasilkan selama proses pemanasan. Pada titik ini granula pati yang mengembang mulai pecah dan diikuti dengan penurunan viskositas. Viskositas maksium tepung talas alami pada penelitian ini adalah 4043,50 cP lebih tinggi dibandingkan yang dilaporkan oleh Kaushal et al. (2012) dan Aprianita et al. (2014) yaitu 1946 cP dan 30 cP. Hal ini dapat disebabkan oleh perbedaan varietas dan komposisi kimia umbi talas yang digunakan. Peak viscosity tepung talas hasil oksidasi/oksidasi iradiasi lebih tinggi dan berbeda signifikan dibandingkan dengan 
peak viscosity tepung talas alami $(p \leq 0,05)$ dan peak viscosity tepung talas hasil oksidasi hidrogen peroksida dan iradiasi sinar UV menunjukkan nilai yang lebih tinggi (4658-4824,50 $c P)$ dan signifikan berbeda $(p \leq 0,05)$ dibandingkan dengan yang hanya diberi perlakuan oksdasi hidrogen peroksida (4988,50-5361,50 cP). Waktu oksidasi/oksidasi-iradiasi 5-30 menit tidak menunjukkan nilai peak viscosity yang berbeda nyata $(p \geq 0,05)$. Kecenderungan yang sama ditunjukkan dengan nilai final viscosity. Peak viscosity tertinggi dihasilkan dari perlakuan oksidasi yang disertai dengan iradiasi UV selama 30 menit yaitu 5361,50 cP dan final viscosity tertinggi dihasilkan pada perlakuan oksidasi yang disertai dengan iradiasi UV selama 5 menit yaitu 3713,00 cP.

Menurut Vanier et al. (2012) peningkatan peak viscosity dan final viscosity pada pati teroksidasi menunjukkan adanya pati ikatan silang (crosslinked starch). Peningkatan peak viscosity dikaitkan dengan pembentukan ikatan silang hemiasetal atau hemiketal dari proses oksidasi yang terjadi hampir disepanjang molekul amilopektin dan pada tingkat yang lebih rendah diantara molekul amilopektin dan amilosa. Menurut Kuakpetoon dan Wang (2006) dan Wang dan Wang (2003) crosslinking meningkatkan berat molekul dan viskositas pasta. Iradiasi UV meningkatkan efektifitas oksidasi sehingga lebih meningkatkan peak viscosity dan final viscosity tepung talas. Kuakpetoon dan Wang (2001) menyatakan tingginya peak viscosity juga disebabkan karena adanya gugus karbonil dan karboksil yang memicu terjadinya swelling pada granula. Hal ini selaras dengan hasil yang ditunjukkan pada Tabel 1 bahwa adanya iradiasi UV pada tepung talas yang dioksidasi hidrogen peroksida memiliki gugus hidroksil yang lebih tinggi.

Breakdown viscosity berhubungan dengan kestabilan pati selama pemanasan. Semakin rendah breakdown viscosity, maka pati semakin stabil pada kondisi panas. Breakdown viscosity merupakan ukuran kemudahan pati yang dimasak untuk mengalami disintegrasi. Breakdown viscosity tepung talas alami pada penelitian ini adalah 1791,00 cP lebih tinggi dibandingkan dengan breakdown viscosity tepung talas yang diungkapkan oleh Kaushal et al., (2012) (200 Cp) dan Kaffah (2012) yaitu 1155,6 Cp. Breakdown viscosity tepung talas alami lebih rendah (1791,00 Cp) tetapi tidak berbeda signifikan dengan breakdown viscosity tepung talas yang hanya diberi perlakuan oksidasi hidrogen peroksida $(1904-2237,50)$ $(p \geq 0,05)$ dan berbeda signifikan dibandingkan dengan tepung talas yang diberi perlakuan oksidasi dan iradiasi UV (2417-2704 Cp) ( $p \leq 0,05)$. Meningkatnya Breakdown viscosity tepung talas yang diberi perlakuan UV menghasilkan tepung talas yang semakin mudah mengalami disintegrasi artinya tidak stabil terhadap pemanasan. Hal ini serupa dengan pati sagu yang dioksidasi dengan hidrogen peroksida dan iradiasi UV selama 10-20 menit meningkatkan breakdown viscosity pati sagu dari -8,5 cP menjadi 5-36 $5 \mathrm{cP}$ (Thetool et al., 2012b).

Nilai kenaikan viskositas ketika pasta pati didinginkan disebut setback viscosity. Kenaikan viskositas yang terjadi disebabkan oleh retrogradasi pati, yaitu bergabungnya rantai molekul amilosa yang berdekatan melalui ikatan hidrogen intermolukuler. Penurunan nilai setback viscosity menunjukkan kecenderungan retrogradasi yang rendah (Kaushal et al., 2012). Nilai setback viscosity tepung talas yang dihasilkan adalah $1120 \mathrm{cP}$ lebih tinggi dibandingkan dengan setback viscosity yang dihasilkan oleh Kaushal et al. (2012) yaitu 487 cP. Hal ini menunjukkan bahwa tepung talas memiliki kecenderungan retrogradasi yang tinggi. Perlakuan oksidasi/ oksidasi-iradiasi menurunkan nilai setback viscosity tepung talas dibandingankan nilai setback viscosity tepung talas alami namun tidak berbeda signifikan $(p \geq 0,05)$. Waktu oksidasi/oksidasi-iradiasi juga tidak menunjukkan perbedaan yang signifikan pada parameter setback viscosity $(p \geq 0,05)$. Penurunan kecenderungan retrogradasi yang terjadi disebabkan oleh adanya gugus karbonil dan karboksil pada molekul pati yang lebih bervolume (bulky) dibandingkan gugus hidroksil dan cenderung menjaga agar rantai amilosa terpisah sehingga menghambat terjadinya retrogradasi 
(Tavares et al., 2010; Liu et al., 2014). Menurut Sandhu et al. (2008) menambahkan bahwa hidrofilisitas gugus karboksil pada molekul pati teroksidasi menurunkan kecenderungan retrogradasi. Nilai setback viscosity terendah dihasilkan dari perlakuan tanpa iradiasi UV selama 30 menit yaitu $692 \mathrm{cP}$.

Pasting temperature (PT) mengindikasikan suhu minimum yang dibutuhkan untuk memasak tepung (Vanier et al., 2017). Tingginya PT mengindikasikan adanya pati yang tahan terhadap pembengkakan dan kerusakan (Khausal et al., 2012). Pasting temperature tepung talas alami sebesar $81,50^{\circ} \mathrm{C}$ lebih rendah dibandingkan dengan pasting temperature tepung talas yang dilaporkan oleh Falade dan Chidinma (2015) yaitu $89,58-91,15^{\circ} \mathrm{C}$. Perbedaan pasting temperature ini dapat disebabkan oleh perbedaan ukuran granula pati pada tepung. Zheng et al. (2013) menyatakan bahwa pasting temperature tergantung pada ukuran granula pati dalam tepung, ukuran granula kecil lebih tahan terhadap kerusakan molekul. Proses oksidasi/oksidasi-iradiasi menghasilkan penurunan pasting temperature tepung talas yang berbeda signifikan dibandingkan dengan pasting temperature tepung talas alami $(p \leq 0,05)$, tetapi antara perlakuan dengan dan tanpa iradiasi UV dan lamanya waktu oksidasi/oksidasi iradiasi tidak menunjukkan perbedaan pasting temperature yang signifikan $(\mathrm{p} \geq 0,05)$. Proses oksidasi/oksidasi iradiasi menurunkan pasting temperature tapung talas menjadi $80,30-80,70^{\circ} \mathrm{C}$ dengan nilai pasting temperature terendah pada perlakuan oksidaisiiradiasi dengan penggunanan UV selama 30 menit $\left(80,30^{\circ} \mathrm{C}\right)$. Penurunan pasting temperature ini disebabkan oleh selama proses oksidasi terjadi pelemahan dan disintegrasi molekul pati (Lawal, 2014). Hasil penelitian ini memeiliki kecenderungan yang sama dengan pati sagu yang dioksidasi menggunakan hidrogen peroksida dan iradiasi sinar UV selama 1020 menit yaitu terjadi penurunan pasting temperature dibandingkan dengan alami (Thetool et al., 2012b) yang disebabkan oleh peningkatan kapasitas hidrasi molekul pati sehingga energi yang dibutuhkan untuk terjadinya proses gelatinisasi menurun (Zaidul et al., 2007; Wang dan Wang, 2003).

Peak time mengindikasikan waktu yang yang dibutuhkan tepung/pati untuk mencapai viskositas maksimum. Peak time tepung talas alami pada penelitian ini adalah 7,37 menit lebih tinggi dibandingkan peak time tepung talas yang dilaporkan oleh Falade dan Chidinma (2015) yaitu 5,17-6,34 menit. Proses oksidasi/oksidasi-iradiasi menghasilkan penurunan peak time tepung talas yang berbeda signifikan dibandingkan dengan peak time tepung talas alami $(p \leq 0,05)$, tetapi antara perlakuan dengan dan tanpa iradiasi UV dan lamanya waktu oksidasi/oksidasi iradiasi tidak menunjukkan perbedaan peak time yang signifikan $(p \geq 0,05)$. Proses oksidasi/oksidasi iradiasi menurunkan peak time tepung talas menjadi 7,20-7,30 menit dengan nilai peak time terendah pada perlakuan oksidasi-iradiasi dengan penggunanan UV selama 30 menit (7,20 menit). Al-Dmoor (2013) menyatakan bahwa penggunaan tepung hasil oksidasi menurunkan suhu gelatinisasi (pasting temperature) dan waktu gelatinisasi (peak time) pati dalam tepung, sehingga aplikasinya pada produk cake memungkinkan cake lebih cepat matang.

\section{KESIMPULAN}

Perlakuan oksidasi tepung talas dengan hidrogen peroksida tanpa atau disertai dengan iradiasi UV mengubah sifat fisiko kimia dan baking expansion tepung talas: meningkatkan kandungan karboksil, menurunkan kecerahan warna (nilai $L, a, b$ ), meningkatkan swelling power dan baking expansion, meningkatkan profil gelatinisasi seperti peak viscosity, final viscosity, dan breakdown viscosity, menurunkan setback viscosity, peak time dan peak temperature, dibandingkan dengan tepung talas alami. Perlakuan oksidasi hidrogen peroksida yang disertai dengan iradiasi UV memiliki karakteristik kandungan karboksil yang lebih tinggi, nilai L, a, b yang lebih rendah, dan peak viscosity, final viscosity, serta 
breakdown viscosity yang lebih tinggi dibandingkan dengan perlakuan oksidasi hidrogen peroksida secara tunggal. Waktu oksidasi/oksidasi-iradiasi (5-30 menit) tidak berpengaruh signifikan terhadap sebagian besar parameter uji. Parameter baking expansion memiliki kecenderungan meningkat pada waktu oksidasi/oksidasi-iradiasi selama 15 menit kemudian menurun pada menit ke 30. Baking expansion tepung talas tertinggi dihasilkan pada perlakuan oksidasi yang disertai dengan iradiasi UV selama 15 menit sebesar $32,46 \%$ dibandingkan tepung talas alami. Perubahan sifat tepung talas hasil oksidasi ini menjadikan tepung talas sesuai diaplikasikan pada pembuatan sup kental, saus sebagai thichener agent karena memiliki peak viscosity yang tinggi dan kecenderungan retrogradasi yang rendah serta dapat pula diaplikasikan pada produk bakery karena memiliki peningkatan baking expansion.

\section{UCAPAN TERIMAKASIH}

Penulis mengucapkan terimakasih pada Kementrian Riset dan Teknologi Pendidikan Tinggi Republik Indonesia dan Pusat Pengembangan Teknologi Tepat Guna-LIPI subkegiatan Rekayasa Sistem Produksi Tepung Umbi Termodifikasi tahun 2017 atas bantuan pendanaan dalam kegiatan penelitian ini.

\section{DAFTAR PUSTAKA}

Aboubakar, Njintang, Y.N., Scher], Mbofung CMF. 2008. Physicochemical, Thermal Properties and Microstructure of Six Varieties of Taro (Colocasia esculenta L. Schott) flours and starches. Journal of Food Engineering 86, 294-305.

Alay, S.C.A dan Maria, A.A.M. 2015. Physicochemical Properties, Modifications and Applications Of Starches From Different Botanical Sources. Food Science and Technology, Campinas 35 (2): 215-236.

Al-Dmoor, H.M. 2013. Cake Flour: Functionality And Quality (Review). European Scientific Journal 9 (3) 1857-7431.

Anindya, A.S. dan Haryadi. 2014. Oksidasi Hancuran Singkong Menggunakan $\mathrm{H}_{2} \mathrm{O}_{2}$ dan Asam Laktat dengan Katalisator Ferrous Sulfate Heptahydrate untuk Meningkatkan Baking Expansion. Jurnal Aplikasi Teknologi Pangan 3(4),128-134.

Aprianita, A., Odor, V., Anna, B., Stefan, K. 2014. Physicochemical Properties of Flours and Starches Derived from Traditional Indonesian Tubers and Roots. Journal of Food Science and Technology 51(12):3669-3679.

Arici, M., Rusen. M.Y., Gorkem,O., Burcu,Y., Omer, S.T. 2016. Physicochemical And Nutritional Properties of Taro (Colocasia Esculenta L. Schott) Flour as Affected by Drying Temperature and Air Velocity. Food Science and Technology Journal 74 ,434440.

Association of Official Agriculture Chemistry (AOAC). (1995). Official Methods of Analysis, $16^{\text {th }}$ Edition. Association of Official Agriculture Chemistry. AOAC Gaithersburg, Maryland

Badan Standardisasi Nasional (BSN). 2009. SNI 3751:2009. Tepung Terigu sebagai Bahan Makanan. BSN. Jakarta

Budiyati, C.S. dan Dessy. 2014. Taro Tube Flour Modification via Hydrogen Peroxide Oxidation. International Journal of Science and Engineering 7(2) 137-142.

Demiate, I.M., Dupuy, N., Huvenne, J.P., Cereda, M.P., Wosiacki, G. 2000. Relationship Between Baking Behavior Of Modified Cassava Starches and Starch Chemical Structure Determined by FTIR Spectroscopy. Carbohydrate Polymers, 42, 149-158. 
Dewi, A.M.P. 2011. Oksidasi Tapioka dengan Hidrogen Peroksida dan Katalis Iradiasi UV C serta Aplikasinya untuk Edible Film. Tesis. Fakultas Teknologi Pertanian, Universitas Gadjah Mada, Yogyakarta.

Dias, A.R.G, Elessandra da R.Z., Moacir, C. E., Elizabethe, Fernanda A de M, Carolina, G.Z., Cesar, F.C. 2011. Oxidation of Fermented Cassava Starch Using Hydrogen Peroxide. Carbohydrate Polymers Journal 86,185-191.

El-Sheikh, M., Mohammed, A. R., Amira, El-S. 2010. Photo-Oxidation Of Rice Starch. Part I: Using Hydrogen Peroxide. Carbohydrate Polymers 80, 266-269.

Ekafitri, R. Peningkatan Kualitas Cake Berbahan Baku Tepung Talas (Colocasia Esculenta L. Schott) Hasil Modifikasi Oksidasi $\mathrm{H}_{2} \mathrm{O}_{2}$ dan Iradiasi Sinar UV. Tesis. Fakultas Teknologi Pertanian, Uiversitas Gadjah Mada, Yogyakarta.

Falade, K.O. dan Chidinma, A.O. 2015. Physical, Functional, and Pasting Properties of Flours From Corms of Two Cocoyam (Colocasia Esculenta And Xanthosoma Sagittifolium) Cultivars. Food Science and Technology Journal 52(6):3440-3448.

Fonseca, L.M, Julia, R.G., Shanise, L.M.E.H., Vania, Z.P., Alvaro, R.G.D., Andressa, C.J., Elessandra da, R.Z. 2015. Oxidation of Potato Starch with Different Sodium Hypochlorite Concentrations and Its Effect on Biodegradable Films. Food Science and Technology Journal 60,714-720.

Jamin, F.F. dan Flores, R.A. 1998. Effect of Additional Separation and Grinding on the Chemical and Physical Properties of Selected Corn Drymilled Streams. Cereal Chemistry Journal 75, 166-170.

Jenie, B.S.L, Helianti, Fardiaz, S. 1997. Pemanfaatan Ampas Tahu, Onggok dan Dedak untuk Produksi Pigmen Merah oleh Monascus Purpureus. Buletin Teknologi dan Industri Pangan 5, 22-29.

Kaffah, F.F.S. 2012. Karakteristik Tepung Talas (Colocasia Esculenta (L) Schott) dan Pemanfaatannya dalam Pembuatan Cake. Skripsi. Fakultas Teknologi Pertanian, Institut Pertanian Bogor, Bogor.

Kaushal, P., Viviek, K., Sharma, H.K.. 2012. Comparative Study Of Physicochemical, Functional, Antinutritional And Pasting Properties Of Taro (Colocasia Esculenta), Rice (Oryza Sativa) Flour, Pigeonpea (Cajanus Cajan) Flour And Their Blends. Food Science and Technology Journal 48, 59-68.

Kuakpetoon, D., dan Wang, Y.J. 2001. Characterization of Different Starches Oxidized by Hypochlorite. Starch/Stärke Journal, 53, 211-218. dan

2006. Structural Characteristics and Physicochemical Properties of Oxidized Corn Starches Varying in Amylose Content. Carbohydrate Research Journal 341, 1896-1915.

Lawal, O. S. (2004). Composition, physicochemical properties and retrogradation characteristics of native, oxidized, acetylated and acid-thinned new cocoyam (Xanthosoma sagittifolium) starch. Food Chemistry. 87: 205-218.

Liu, J., Wang, B., Lina, L., Zhang, J., Liu, W., Xie, J., Ding, Y. 2014. Functional, Physicochemical Properties and Structure of Cross-Linked Oxidized Maize Starch. Food Hydrocolloids Journal 36, 45-52.

Rivera, M.M.S., Garcia, S.F.J.L., del Valle, M.V., Meraz, F.G., Bello-Perez, L.A . 2005. Partial Characterization of Banana Starches Oxidized by Different Levels of Sodium Hypochlrite. Carbohydrate Polymer 62: 50-56.

Sandhu, K.S., Kaur, M., Singh, N., Lim, S. 2008. A Comparison Of Native and Oxidized Normal And Waxy Corn Starches: Physicochemical, Thermal, Morphological and Pasting Properties. Food Science and Technology Journal 41, 1000-1010. 
Sausania, A. 2014. Oksidasi dan Iradiasi Tepung Ubi Kayu dengan Hidrogen Peroksida dan Sinar UV-C Menggunakan Tumbler untuk Meningkatkan Baking Expansion. Tesis. Fakultas Teknologi Pertanian Universitas Gajdah Mada, Yogyakarta.

Sangseethong, K., Termvejsayanon, N., Sriroth, K. 2010. Characterization of Physicochemical Properties of Hypochlorite and Peroxide-Oxidized Cassava Starches. Carbohydrate Polymers Journal 82, 446-453.

Setya, A. 2015. Iradiasi Sinar UV-C pada Hancuran Singkong dalam Larutan Asam Laktat Hidrogen Peroksida untuk Mendapatkan Tepung dengan Baking expansion yang Meningkat. Jurnal Aplikasi Teknologi Pangan4(1), 17-21.

Singh, J., Kaur, L., McCarthy, O.J. 2007. Factors Influencing the Physico-Chemical, Morphological, Thermal and Rheological Properties of Some Chemically Modified Starches For Food Applications-A Review. Food Hydrocolloids Journal 21, 1-22.

Srichuwong, S., Sunarti, T.C., Mishima T, Isono N, Hisamatsu M. 2005. Starches From Different Botanical Sources II: Contribution Of Starch Structure To Swelling And Pasting Properties. Carbohydrate Polymer Journal, 62:25-34.

Syamsir, E., Purwiyatno, H., Dedi, F., Nuri, A., Feri, K. 2012. Pengaruh Proses Heat Moisture Treatment (HMT) terhadap Karakteristik Fisikokimia Pati. Jurnal Teknologi dan Industri Pangan 13 (1) : 100-106....

Tavares, A.C.K., Zanatta, E., Zavareze, E.R., Helbig, E., Dias, A.R.G. 2010. The Effect of Acid and Oxidative Modification on The Expansion Properties of Rice Flours With Varying Levels of Amylose. LWT-Food Science And Technology 43 : 1213-1219.

Tethool, E.F., Abadi, J., dan Budi, S. 2012a. Pengaruh Konsentrasi Hydrogen Peroxida Dan Iradiasi Ultraviolet Terhadap Sifat Fisikokimia dan Baking Expansion Pati Sagu. Prosiding Insinas 331-335 , dan 2012b. Characterization of Physicochemical and Baking ExpansionProperties of Oxidized Sago Starch Using Hydrogen Peroxide and Sodium Hypochlorite Catalyzed By UV Irradiation. Food Science and Quality Management Journa/10, 1-11.

Tester, R.F. dan Morrison, W.R. 1990. Swelling Gelatinization of Cereal Starches I. Effect of Amylopectin, Amylase And Lipids. Cereal Chemistry Journal 67: 551-557.

Vatanasuchart, N., Naivikul, O., Charoenrein, S. S. K. 2005. Molecular Properties of Cassava Starch Modified With Different UV Irradiations To Enhance Baking Expansion. Carbohydrate Polymers Journal 61, 80-87.

Vanier, N.L., Zavareze, E.R., Pinto, V.Z., Klein, B., Botelho, F.T., Dias, A.R.G, Elias, M.C. 2012. Physicochemical, Crystallinity, Pasting And Morphological Properties of Bean Starch Oxidised By Different Concentrations of Sodium Hypochlorite. Food Chemistry Journal 131, 1255-1262.

Vanier, N.L., Shanise, L.M.E.H., Alvaro, G.D., E da, R.Z. 2017. Molecular Structure, Functionality and Applications of Oxidized Starches: A Review. Food Chemistry Journal 221, 1546-1559.

Wang, Y.J., dan Wang, L. 2003. Physicochemical Properties of Common and Waxy Corn Starch Oxidized Bydifferent Level of Sodium Hypochlorite. Carbohydrate Polymers Journal 52 : 207-217.

Yadav, A.R., Guha, M., Tharanathan, R.N., Ramteke, R.S. 2006. Changes in Characteristics of Sweet Potato Flour Prepared by Different Drying Techniques. Food Science and Technology Journal 39:20-26.

Zaidul, I.S.M., Norulaini, N.A.N., Omar, A.K.M., Yamauchi, H., Noda, T. 2007. RVA analysis of mixtures of wheat flour and potato, sweet potato, yam, and cassava starches. Carbohydrate Polymer Journal 69:784-791. 
Zeng, F., Liu, H., Liu, G. 2013 Physicochemical properties of starch extracted from Colocasia esculenta (L.) Schott (Bun-long taro) grown in Hunan, China. Starch/Stärke Journal 65:1-7.

Zhou, F., Qian, L., Hongwei, Z., Qian, C., Baohua, K. 2016. Potato Starch Oxidation Induced by Sodium Hypochlorite and Its Effect on Functional Properties and Digestibility. International Journal of Biological Macromolecules Journal 84 : 410-417. 